\title{
Erişkinde Farklı Klinik Bulgularla Seyreden Split Kord Malformasyonu Olguları
}

Split Cord Malformation Cases With Different Clinical Findings in Adults Sezin Solum ${ }^{1}$ (D), illknur Aykurt Karlıbel ${ }^{2}$ (D), Meliha Kasapoğlu Aksoy ${ }^{2}$

1 Fiziksel Tıp ve Rehabilitasyon Kliniği, Kestel Devlet Hastanesi, Bursa/Türkiye

2 Fiziksel Tıp ve Rehabilitasyon Kliniği, Sağlık Bilimleri Üniversitesi, Bursa Yüksek İhtisas EAH, Bursa/Türkiye

\section{$\ddot{O Z E T}$}

Split Kord Malformasyonu (SKM) omuriliğin fibröz bant, kemik ya da kıkırdak dokuyla ikiye bölünmesiyle karakterize nadir görülen bir embriyolojik anomalidir. Genellikle alçak yerleşimli konus ve tethered kord ile birlikte bulunur. Tanıda manyetik rezonans görüntüleme ve bilgisayarlı tomografi yardımcıdır. Tanı genellikle çocukluk döneminde konulmakla birlikte nadiren erişkin dönemde de konulabilmektedir. Tedavi şekli, çocuklarda genellikle cerrahi olmakla birlikte, nadiren semptom gösteren erişkinlerde tartışmalıdır. Hem "bekle ve izle"yaklaşımı hem de profilaktik cerrahi, çeşitli şekillerde savunulmuştur. Bu makalede erişkin dönemde tanı konulan 4 SKM deneyimimiz anlatılmaktadır. Yetişkinlerde SKM hakkındaki literatürün kapsamlı bir incelemesi sunulurken cerrahi dışı tedavi sonuçları da değerlendirilmiştir.

Anahtar Kelimeler: yetişkin, split kord malformasyonu, spinal disrafizm, bağıı kordon

\section{ABSTRACT}

Split cord malformation is a rare embryological anomaly characterized by the division of the spinal cord into a fibrous band, bone or cartilage tissue. It is usually found with a low lying conus and tethered cord. Magnetic resonance imaging and computed tomography are helpful in the diagnosis. The diagnosis is usually made in childhood, but rarely in adulthood. Here we report a case of 4 cases of split cord malformation diagnosed in adulthood and showing different clinical findings.

Keywords: adult, split cord malformation, spinal dysraphism, tethered cord

\section{GíRiş}

Split kord malformasyonu (SKM) nadir görülen gelişimsel embriyolojik bir orta hat anomalisidir ve tüm konjenital spinal anomalilerin \%3,8 ile \%5'ini temsil eder (1). Spinal kordun orta hattan kemik veya fibrokartilajinöz bir septum ile sagittal olarak iki ayrı segmente ayrılması olarak tanımlanabilir. Bu ayrıma komplet ya da inkomplet olabilmektedir (2). SKM genellikle çocukluk döneminde tanı konulan bir hastalık olmakla birlikte yaşamın herhangi bir döneminde de semptomatik olabilmektedir. Çocukluk çağında semptomlar bel ağrısı, bacakta güçsüzlük, skolyoz, omurga ve ayak deformiteleri olarak sayılabilir (3). Adölesan ve erişkin dönemde ise SKM'li hastalar ilerleyici duysal ve motor kayıplarla karşımıza çıkabilmektedir $(4,5)$. Çocuklarda sensörimotor semptomlar tipik olarak erken cerrahi ile tedavi edilir. Erişkin dönem SKM'de cerrahi tedavi tartışmalıdır (6). Bazı yazarlar pediatrik temele dayalı yetişkin SKM'de profilaktik cerrahi önerirken diğerleri nörolojik kaybı olmayan hastalarda beklemeyi önermektedir (7).
Bu yazıda amacımız bel ağrısıyla polikliniğimize başvuran, alçak yerleşimli konusun da eşlik ettiği geç tanı konulan SKM'ye sahip dört yetişkin olguyu sunarken literatürün kapsamlı bir incelemesini yapmak ve cerrahi dışı tedaviyi tartışmaktır.

\section{OLGU 1}

50 yaşında kadın hasta polikliniğimize 2 yıldır olan ve son 1 yıldır artan bel ve sağ bacak ağrısı şikâyeti ile başvurdu. Bilinen bir travma öyküsü yoktu. Valsalva manevrası ile, öne eğilmekle artan ve sağ bacakta uyuşma, karıncalanmanın eşlik ettiği mekanik karakterde bir ağrı tarif ediyordu. Son bir yıldır bu şikâyetlerine idrar ve gaita inkontinansı eşlik etmekteydi. Yapılan fizik muayenede lomber bölgede kıllanma artışı, lordozda artış ve açıklı̆ı̆ sola bakan skolyoz mevcuttu (Resim 1). Bilateral ekstansör hallusis kas güçleri 4/5 düzeyindeydi ve Babinski refleksi bilateral lakayt olarak değerlendirildi. Mevcut bulgularla hastada spinal disrafizm düşünülerek lomber manyetik rezonans görüntüleme (MRG) tetkiki istendi. Çekilen lomber MRG'de medulla spinalisin L3 seviyesinde sonlandığı (alçak yerleşimli konus)

Yazışma Adresi/Address for Correspondence: Sezin Solum, MD, Ahmet Vefik Paşa, Ankara Bulvarı No 2416450 Kestel, Bursa/Türkiye E-Posta/E-Mail: sezinsolum@hotmail.com || Tel: +90224502 8016

Received/Geliş Tarihi: 26 Mar 2019 || Accepted/Kabul Tarihi: 02 Ağu 2019

Bu Eser Creative Commons Atıf-Gayriticari 4.0 Uluslararası Lisansı İle Lisanslanmıştır. This work is licensed under a Creative Commons

Attribution-NonCommercial 4.0 International License (CC BY-NC 4.0). 
ve L1-L2 seviyesinde spinal kordu ikiye ayıran kemik spur formasyonu saptandı (Resim 2). Tip 1 split kord malformasyonu (diyastomatomiyeli) ile uyumluydu. Ayrıca bu düzeyde posterior elemanlarda kapanma defekti de eşlik etmekteydi. Hastaya skolyoz için egzersiz programı ve ağrı kontrolü için medikal tedavi verilerek Beyin Cerrahisi konsültasyonu istendi. Beyin Cerrahi kliniği tarafından operasyon önerildi ancak hasta kabul etmedi.

Resim 1. Lumbosakral bölgede kıllanma artışı

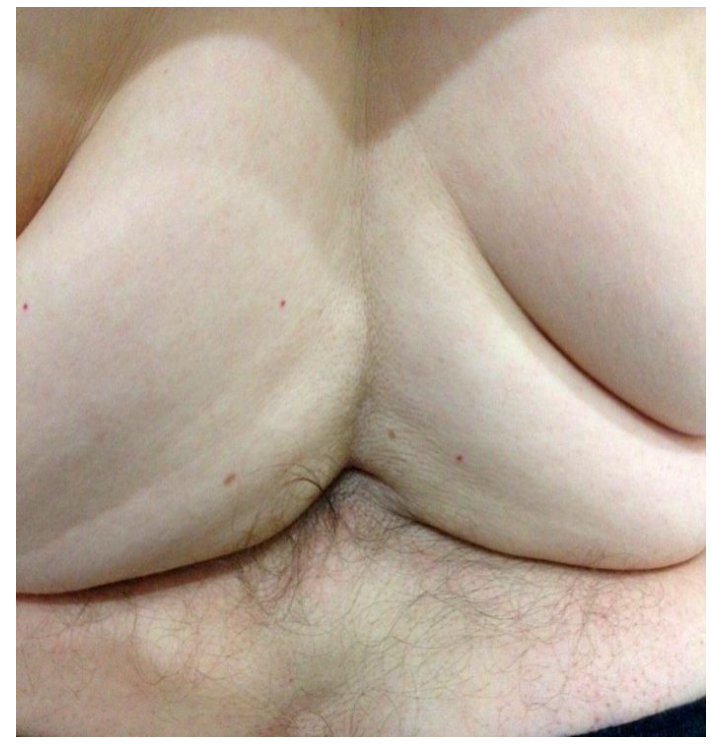

Resim 2. T2 ağırlıklı sagittal kesit MRG incelemesinde split kord malformasyonu görüntüsü

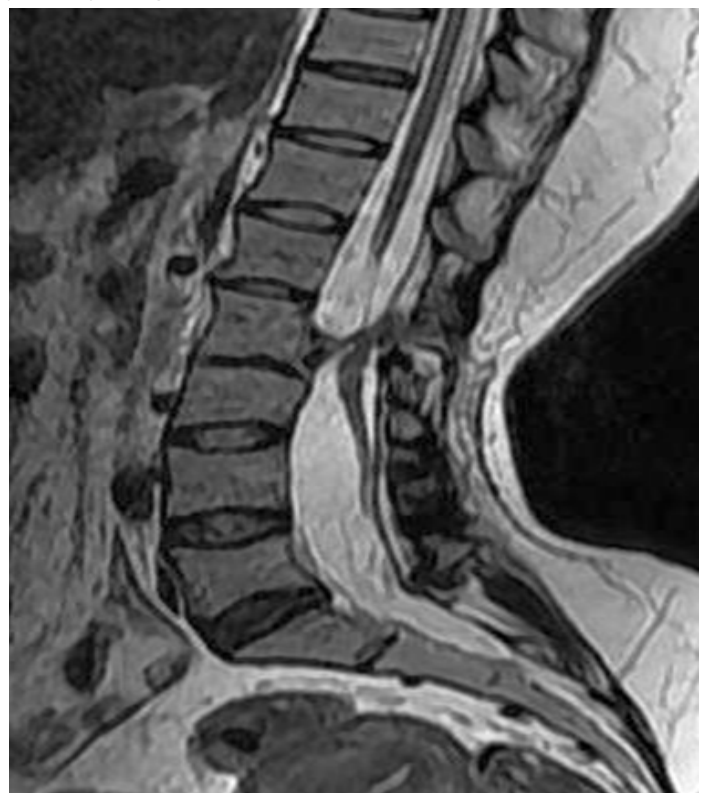

\section{OLGU 2}

38 yaşında kadın hasta son bir yıldır olan, ayakta durmak ve yürümekle artan belden sol bacağa yayılan ağrı ve uyuşma şikâyeti ile polikliniğimize başvurdu. İdrar ve gaita inkontinansı tarif etmiyordu. Fizik muayenede lomber bölgede gamze ve lordozda artış mevcuttu (Resim 3). Her iki alt ekstremitede belirgin atrofi olup derin tendon refleksleri alınamıyordu. Sol kalça fleksiyonunda 1/5 değerinde güç kaybı tespit edildi. Spinal disrafizm düşünülerek lomber MRG istendi. Lomber MRG'de L2-L3 vertebra seviyesinde anterior füzyon olup konus medullaris L3-L4 seviyesinde sonlanmaktaydı. L1-L2 seviyesinde kordu ayıran kemik spikül ile diyastomatomiyeli (Tip 1 split kord malformasyonu) görünümü mevcuttu (Resim 4, Resim 5). Beyin Cerrahi konsültasyonu istenen hasta önerilen operasyonu kabul etmedi.

\section{Resim 3. Spinal gamze görünümü}

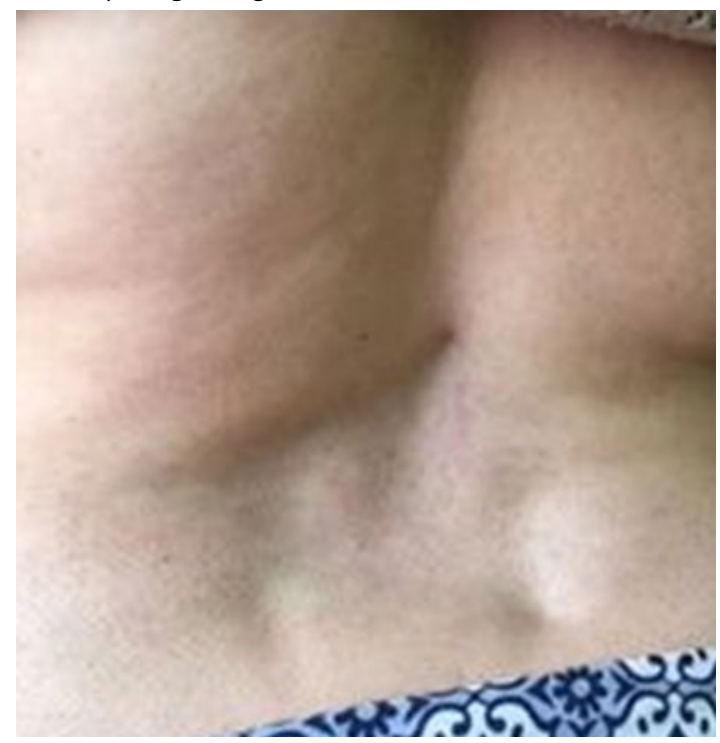

Resim 4. T2 ağırlıklı sagittal kesit MRG incelemesinde split kord malformasyonu görüntüsü

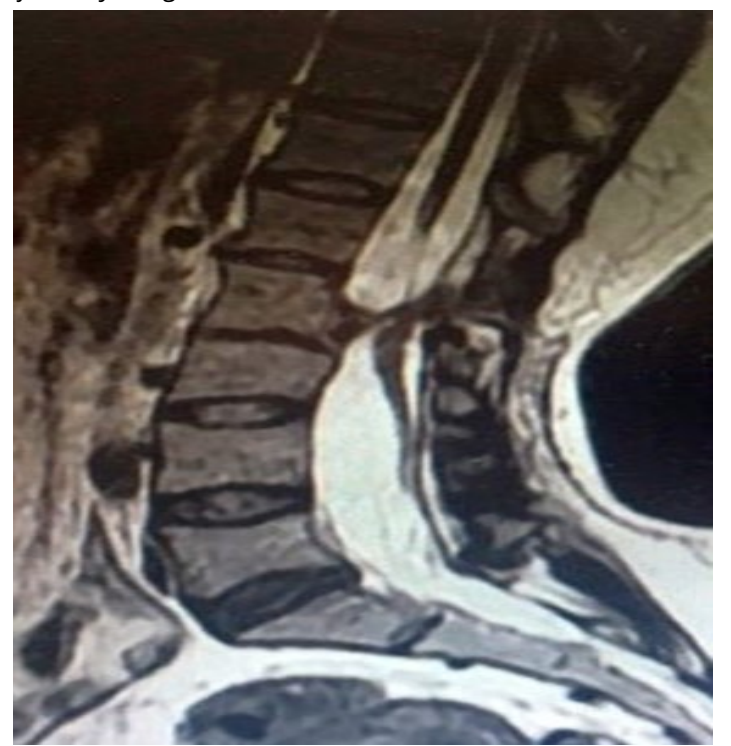


Resim 5. T2 ağırlıklı transvers kesit MRG incelemesinde diyastomatomiyeli görünümü (Tip 1)

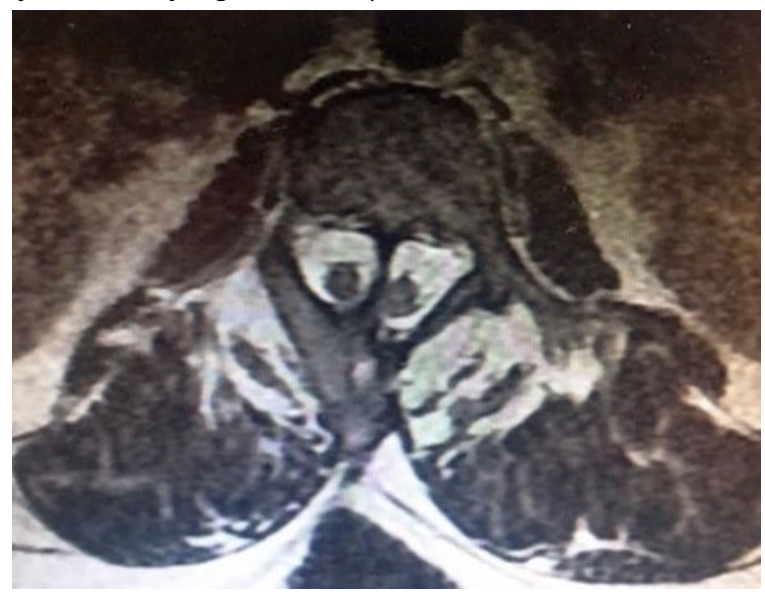

\section{OLGU 3}

39 yaşında kadın hasta polikliniğimize 4-5 yıldır olan ve birkaç aydır artan bel ağrısı ve sağ alt ekstremitede uyuşma şikâyeti ile başvurdu. İdrar gaita inkontinansı yoktu. Sağ ayak numarası soldan 2 numara daha küçüktü ve pes kavus mevcuttu. Fizik muayenesinde sağ alt ekstremitede sola göre $2 \mathrm{~cm}$ atrofi tespit edildi. Sağ alt ekstremitede derin tendon refleksleri alınamıyordu. Lomber bölgede gamze mevcuttu. Spinal disrafizm düşünülerek istenen lomber MRG'de medulla spinalis L4 seviyesinde sonlanmakta (alçak yerleşimli konus) ve L3-L4 seviyesinde diplomiyeli görünümü mevcuttu. Aynı zamanda tethered kord eşlik etmekteydi.

\section{OLGU 4}

52 yaşında kadın hasta polikliniğimize yaklaşık 7 yıldır olan bel ağrısı ve omurgada şekil bozukluğu şikâyeti ile başvurdu. Sorgulamasında idrar inkontinansı tarif etmekteydi. Fizik muayenesinde inspeksiyonda sol omuzda düşüklük, torakal kifozda artış, skolyoz ve lomber bölgede kıllanma artışı mevcuttu (Resim 6, Resim 7). Nörolojik kayıp yoktu. Spinal disrafizm düşünülerek istenen lomber MRG'de L3-L4 seviyesinde diyastomatomiyeli ile uyumlu görünüm saptandı ve tethered kord da eşlik etmekteydi (Resim 8, Resim 9).

Dört hastaya da Beyin Cerrahisi kliniğince cerrahi tedavi önerildi. Ancak hastaların hiçbiri cerrahi tedaviyi kabul etmedi. Bu nedenle hastalara ağrı medikasyonu ile birlikte fizik tedavi ve egzersiz programı önerildi. Yaklaşık bir yıllık takipleri süresince nörolojik muayenelerinde bir kötüleşme saptanmadı.
Resim 6. Sol omuzda düşüklük ve skolyoz görünümü (Tip 1)

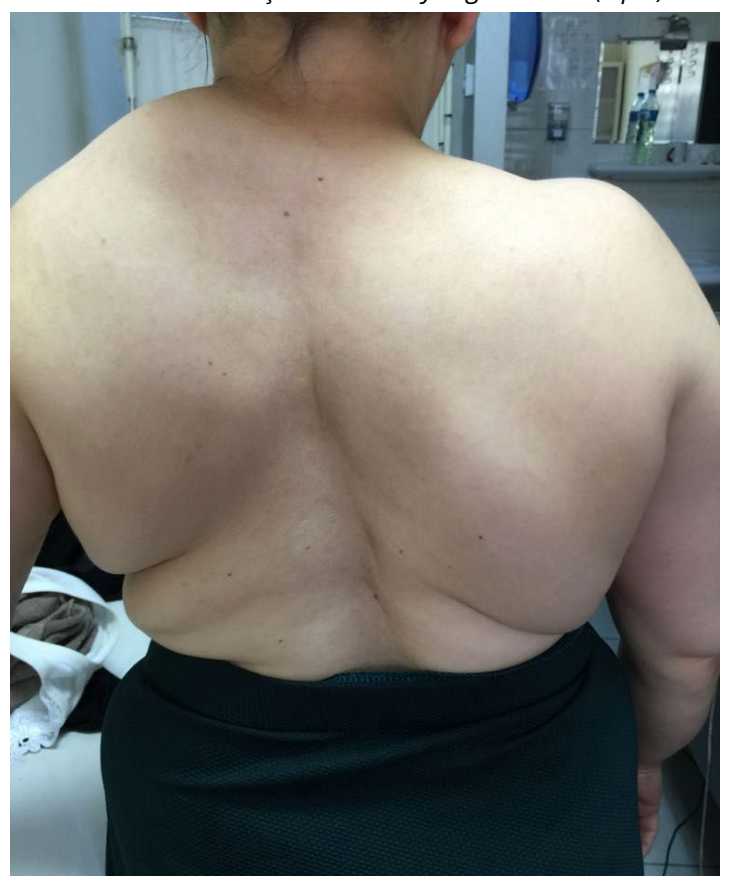

Resim 7. Lumbosakral bölgede kıllanma artışı

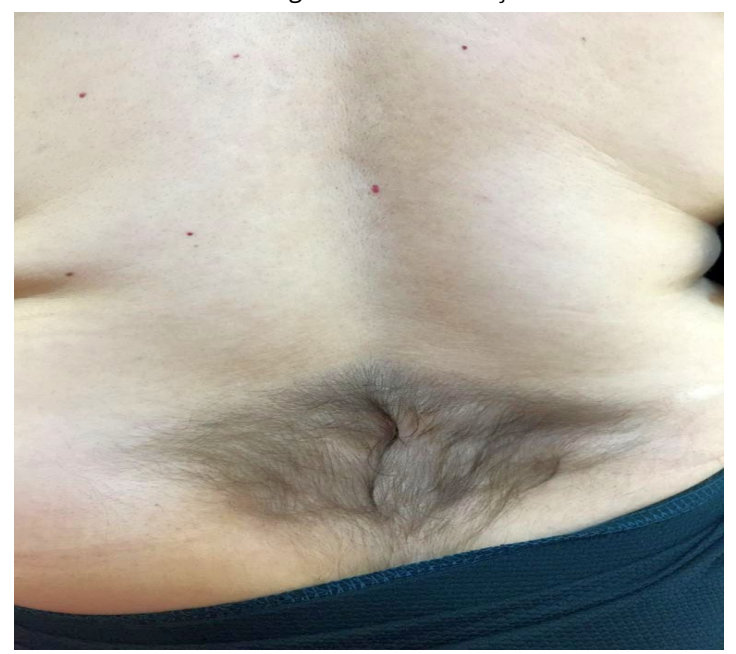

Resim 8. T2 ağırlıklı transvers kesit MRG incelemesinde diyastomatomiyeli görünümü (Tip 1).

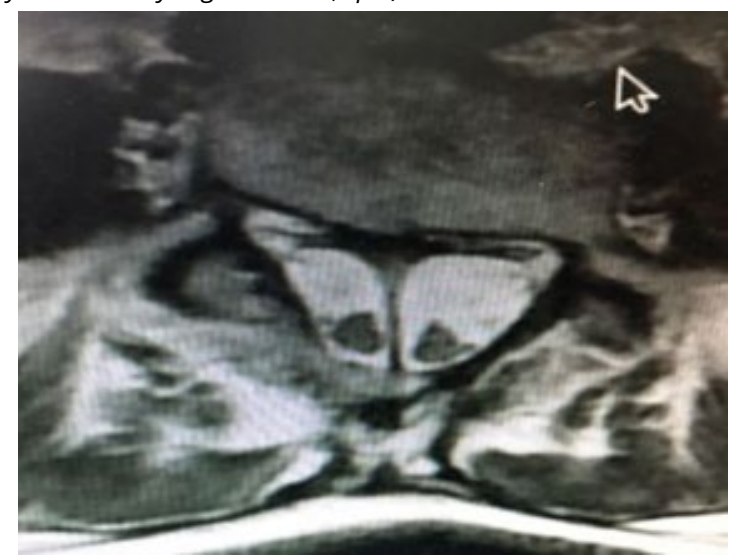


Resim 9. T2 ağırlıklı sagittal kesit MRG incelemesinde split kord malformasyonu görüntüsü

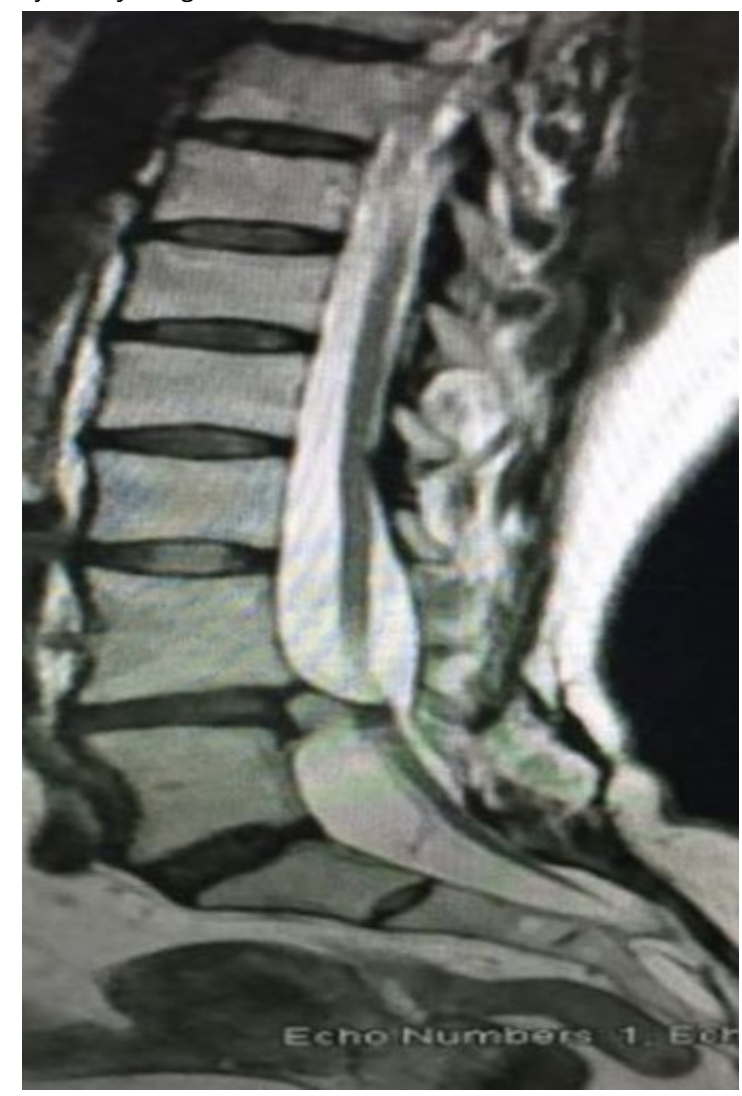

\section{TARTIŞMA}

SKM, spinal kordun nadir görülen bir konjenital anomalisidir. Illk defa 1937 yılında Ollivier (8) tarafından kullanılan bu terim omuriliğin longitudinal eksende fibröz bant, kemik veya kıkırdak dokuyla iki ayrı segmente ayrılması olarak tanımlanabilir. Pang (9) 1992 yılında SKM'nin iki tipi olduğunu bildirmiştir. Tip 1 SKM'de (diyastomatomiyeli) tam olarak ayrılmış iki hemikord vardır ve her iki omurilik kendi dural kılıfı ile sarılıdır. Septum kemik ya da kıkırdak dokudan oluşur. Tip 2 SKM'de (diplomiyeli) aynı dural kılıf içerisinde iki hemikord vardır. Kord ince fibröz bant ile birbirinden ayrılmıştır $(9,10,11)$. Büyük olgu serilerinin birçoğunda, tip I SKM'lerin tip II lezyonlardan daha sık olduğu tahmin edilmektedir $(10,12,13)$.

Embriyolojik olarak embriyonel hayatın gastrülasyon döneminde primitif nöroenterik kanalın kapanmasındaki temel bir ontogenetik hatadan kaynaklanmaktadır (9). Etiyolojisi tam olarak bilinmemekle birlikte aşırı alkol tüketimi, karbamazepin, valproik asit, hipertermi ve obezite suçlanan faktörler arasındadır (14). Folik asit eksikliği de artmış risk ile ilişkilidir (14).
SKM en sık T9-L3 seviyesinde görülmektedir. Septumun \%50'si L1-L3, \%25'i T7-T12 arasında yerleşim gösterir. Çok nadiren servikal ve üst torakal yerleşim de görülebilmektedir (15-18). Kadın cinsiyette görülme oranı daha fazladır $(9,19,20)$. SKM izole olabileceği gibi tethered / alçak yerleşimli kord (\%50), kifoskolyoz (\%44-\%60), siringomiyeli (\%27,5-\%44) ile birlikte bulunabilir. Spinal disrafizmin diğer formları olan dermoid kist, nöroenterik kist ve spinal lipom (\%11-\%26) da SKM'ye eşlik edebilmektedir $(10,12,21)$. Bu yazıda bizim sunmuş olduğumuz olgularda da kadın hâkimiyeti olup lomber bölge yerleşimi görülmektedir ve alçak yerleşimli konus eşlik etmektedir. Olgularımızın 3'ü tip 1 SKM iken 1 'i Tip 2 SKM'dir.

SKM sıklıkla çocukluk döneminde saptanmaktadır. Klinik bulguların ortaya çıkışı genellikle 4-6,5 yaşları arasındadır (22). Asemptomatik hastaların bir kısmı bizim olgularımızda olduğu gibi erişkin dönemde semptomatik hale gelebilmektedir. Asemptomatik olgularda genellikle cilt bulguları ve vertebra anomalileri bulunmaktadır. Cilt bulguları arasında fokal kıllanma, hemanjiyom, gamze, lipom ve telenjiektazi sayılabilir (12). Hemivertebra, skolyoz, konjenital bar eşlik edebilen vertebral anomalilerdir (23). Erişkin dönemde görülen semptomlar arasında kronik bel ağrısı, alt ekstremitede motor kayıp ve duyu kaybı yer alır. Tekrarlayıcı ve kronik bel ağrısı çocukların \%30'unda, erişkinlerin ise tamamında vardır. Bazı olgularda mesane disfonksiyonu da görülebilmektedir (12,24). Bizim olgularımız da benzer bulgulara sahip olup kendi içinde farklılıklar göstermektedir (Tablo 1).

SKM tanısında MRG tercih edilen yöntemdir. MRG hem spinal kord deformiteleri hem de vertebral anatomi hakkında bilgi vermektedir. SKM tanısının konulmasında ve preoperatif dönemde ameliyat yöntemini planlamada önemli bir yere sahiptir. Günümüzde SKM tanısındaki yerini MRG'ye bırakan bilgisayarlı tomografi (BT) kemik septum ve vertebra anomalilerinin görüntülenmesinde yararlıdır $(25,26)$. SKM tanısı temel olarak görüntüleme yöntemlerine dayanmaktadır. Farklı görüntüleme yöntemlerinin birbirlerine göre avantajları ve dezavantajları bulunmaktadır. Bu nedenle tanıda SKM tipini, vertebra yapısını ve SKM ile ilişkili malformasyonları belirleyebilecek normal spinal MRG ve tüm omurga 3D BT rekonstrüksiyon 
tekniği kombinasyonunun kullanılması önerilmektedir (27). Bizim olgularımızda tanı MRG ile konulmuştur.

Prenatal dönemde, üçüncü trimesterde sonografik inceleme ile vertebranın posterior elemanları ve fetal spinal lamina arasındaki ekojenik odak saptanarak SKM tanısı konulabilmektedir (28). Prenatal tanı için Maternal Alfa-Feto Protein (MAFP) düzeyinin ölçümü de önerilmektedir. Artmış MAFP düzeyleri SKM ile ilişkilidir (29). Prenatal tanı doğum sonrası cerrahi yaklaşım açısından önem taşımaktadır (22).

SKM'nin tedavisi cerrahidir. Nörolojik, ürolojik ya da ortopedik bir problem olsun ya da olmasın tanı konulur konulmaz opere edilmesi önerilmektedir $(30,31)$. Özellikle çocuk hastalarda profilaktik cerrahi gereklidir (12,31). Bununla birlikte, SKM'li erişkinlerde cerrahi endikasyonları ve gerekçeleri hala büyük ölçüde tanımlanmamıştır $(32,33)$. İlerleyen yaşlarda özellikle minör travmalara bağlı nörolojik kayıp gelişme riski arttığından dolayı erken dönemde operasyon önerilmektedir (3,31). Cerrahide amaç, omuriliği ikiye ayıran septumu ya da kordu transfikse edebilecek fibronörovasküler bandı çıkartarak omuriliği serbestleştirmektir (34).

Tablo 1. Hastaların demografik, klinik özellikleri, uygulanan tedavi ve takip sonuçları

\begin{tabular}{|c|c|c|c|c|}
\hline Demografik Özellikler & Olgu 1 & Olgu 2 & Olgu 3 & Olgu 4 \\
\hline Yaş & 50 & 38 & 39 & 52 \\
\hline Erkek & - & - & - & - \\
\hline Kadın & + & + & + & + \\
\hline Semptom Süresi (Yıl) & 2 & 1 & 5 & 7 \\
\hline \multicolumn{5}{|l|}{ Semptomlar } \\
\hline Bel Ağrısı & + & + & + & + \\
\hline Bacak Ağrısı & + & + & + & - \\
\hline Parestezi & + & + & + & - \\
\hline Hissizlik & + & + & + & - \\
\hline $\begin{array}{l}\text { Alt Ekstremitede } \\
\text { Güçsüzlük }\end{array}$ & + & + & - & - \\
\hline Atrofi & - & + & + & - \\
\hline Gaita İnkontinansı & + & - & - & - \\
\hline İdrar İnkontinansı & + & - & - & + \\
\hline Skolyoz & + & - & - & + \\
\hline Kıllanma Artışı & + & - & - & + \\
\hline Sakral Gamze & + & + & + & - \\
\hline Ayak Deformitesi & - & - & + & - \\
\hline \multicolumn{5}{|l|}{ Radyolojik Özellikler } \\
\hline \multicolumn{5}{|l|}{ Low-lying Konus } \\
\hline \multicolumn{5}{|l|}{ Konus L2 } \\
\hline Konus L3 & + & & & \\
\hline Konus 14 & & + & + & + \\
\hline Tethered kord & + & + & + & + \\
\hline \multicolumn{5}{|l|}{ Tedavi } \\
\hline Konservatif Tedavi & + & + & + & + \\
\hline Cerrahi Tedavi & - & - & - & - \\
\hline $\begin{array}{c}\text { Nörolojik Defisitte } \\
\text { Illerleme }\end{array}$ & - & - & - & - \\
\hline
\end{tabular}

Vakalarımızın hepsinde alçak yerleşimli konus ve tethered kord mevcuttu. Tethered kordun eşlik ettiği semptomatik olan erişkin hastaların opere edilmesi önerilmektedir. Opere edilen hastalarda ağrıda büyük ölçüde azalma sağlanmaktadır. Ayrıca konservatif olarak tedavi edilen hastalarla karşılaştırıldığında opere edilenlerde nörolojik kayıpta artış gelişme riskinin daha az olduğu saptanmıştır. Revizyon operasyonlarının sadece kompleks disrafik lezyonu olan seçili olgularda uygulanması önerilmektedir (33).

Bizim vakalarımız SKM tanısı konulduktan sonra Beyin Cerrahi kliniğine yönlendirildi ve tüm olgulara operasyon önerildi. Ancak hastaların hiçbiri operasyonu kabul etmediler. Bununla birlikte konservatif tedavi yöntemleri kullanılarak semptomatik tedavi (fizik tedavi, nöropatik ağrı için medikasyon, kas güçlendirmeye yönelik egzersizler, vb.) uygulandı. Hastaların bir yıllık takipleri süresince nörolojik kayıplarında artış tespit edilmedi. Asemptomatik hastalarda, lezyonun birçok kişide yıllarca sessiz kaldı̆̆ düşünüldüğünde "bekle ve izle" yaklaşımı uygulanabilir. Ancak non-operatif tedaviye yanıt vermeyen bel-bacak ağrısı olan hastalar için bu uygun bir seçenek olarak görülmemiştir (7).

Erişkinde SKM nadir görülmekte ve kolaylıkla atlanabilmektedir. İlerleyici bel ağrısı, skolyoz, yürüme güçlüğü, cilt bulguları, ürolojik semptomları olan erişkinde ayırıcı tanıda split kord malformasyonu da düşünülmelidir. Tanıda MRG ve BT önem arz etmektedir. Konus medullarisin L2'nin altında sonlanması tethered kordu düşündürmektedir. Erişkin dönemde tanı konulan tethered kordun eşlik ettiği semptomatik olgulara operasyon önerilmelidir.

$$
\begin{aligned}
& \text { Yazarlar arasında çıkar çatışması yoktur. } \\
& \text { The author declares no conflict of interest. } \\
& \text { Finansal Destek: yoktur / Funding : none } \\
& \text { doi: https://doi.org/10.33713/egetbd.545061 }
\end{aligned}
$$

\section{KAYNAKLAR}

1. Tortori-Donati PT, Rossi A, Biancheri $R$, et al: Congenital malformations of the spine and spinal cord. InTortori-Donati PT, Rossi A, (eds): Pediatric Neuroradiology: Brain, Head, NeckandSpine, 1st ed. New York: Springer-Verlag, 2005. pp. 1587-1594.

2. Dias MS, Pang D. Split kord malformations. Neurosurg Clin 
North Am 1995; 6: 339-358.

3. Tatlı M, Güzel A, Karadağ Ö. Ayrık omurilik malformasyonları. Cumhuriyet Üniv Tıp Fak Derg 2004; 26: 97-98.

4. Kardağ Ö, Aslan A, Gürelik M, Göksel HM. Ayrık omurilik malformasyonu: iki olgu sunumu. Cumhuriyet Üniv Fak Derg 2002; 24: 153-7.

5. Keminker R, Fabry J, Midha R, Finkelstein JA. Split cord malformation with diastematomyelia presenting as neurogeniccladication in adult. Spine 2000; 25: 2269-71.

6. Akay KM, İzci Y, Baysefer A, Timurkaynak E. Split cord malformation in adults. Neurosurg Rev 2004; 27: 99-105.

7. Visvanathan VK, Minnema AJ, Farhadi HF. Surgical managementof adult type 1 split cord malformation. Report of two cases with literature review. J Clin Neuroscience 2018; 52:119-121.

8. Ollivier CP. Traitesdesmaladies de la moelleepiniere. 3rd ed. Paris: Mequignon Marvis, 1937:1.

9. Pang D, Dias MS, Ahab-Barmada M. Split cord malformation: Part 1: A unifiedtheory of embryogenesis for double spinal cord malformations. Neurosurgery 1992; 31: 451-480.

10. Pang D. Split cord malformation: Part 2: Clinical syndrome. Neurosurgery 1992; 31: 481-500.

11. Reigel DH, McLone DG. Tethered spinal cord. In: Cheek WR, Marlin AE, McLone DG, Reigel DH, Walker ML (eds) Pediatric neurosurgery: surgery of the developing nervous system, 3rd edn, chap 4. Saunders, Philadelphia. 1994; pp 77-95.

12. Sinha S, Agarwal D, and Mahapatra AK: Split cord malformations: an experience of 203 cases. Childs Nerv Syst 2006; 22: 3-7.

13. Cheng B, Li FT, and Lin L: Diastematomyelia: a retrospective review of 138 patients. J Bone Joint Surg Br 2012; 94: 365-372.

14. Shurtleff DB, Lemire RJ. Epidemiology, etiologic factorsand prenatal diagnosis of open spinal disraphysm. Neurosurg Clin North Am 1995; 6: 183-193.

15. Orakdöğen $M$, Türk CC, Erşahin $M$, Biber $N$, Berkman Z. Spinal dysraphisms of cervicothoracic region in childhood. Turk Neurosurg 2009; 19: 400-405.

16. Erman $T$, Göçer Ai, Tuna $M$, İldan F, Çetinalp E. Gergin omurilik sendromu. Türk Nöroşirurji Dergisi 2000; 10: 211-217.

17. Liu W, Zheng D, Cui S, Zhang C, Liu Y, Jia $Y$, Shi T, Huang $H$, Hei B, Wang P. Characteristics of osseous septum of splitcordmalformation in patients presenting with scoliosis: A retrospective study of 48 cases. Pediatr Neurosurg 2009; 45: 350-353.

18. Huang S-L et al: Diastematomyelia: a 35-year experience. Spine 2013; 38:344-349.

19. Anderson FM. Occult spinal dysraphism: A series of 73 cases. Pediatrics 1975; 55: 826-835.

20. Iskander BJ, Mclaughlin C, Oakes WJ. Split cord malformation in myelomeningocele patients. $\mathrm{Br} J$ Neurosurg 2000; 14: 200-203.
21. Mahapatra AK, andGupta DK: Split cord malformations: a clinical study of 254 patients and a proposal for a new clinicalimaging classification. J Neurosurg 2005; 103: 531-536.

22. Warf BJ. Tethered spinal cord. In: Winn HR, editor. Youmans neurological surgery. Philadelphia: Saunders Company; 2004. p. 3257-87.

23. Gery M, Rowe LJ, Yochum TR, Thompson JR, Maola CJ. Congenital anomalies and normal skeletal variants. In: Yochum TR, Rowe LJ, editors. Essentials of Skeletal Radiology. Third ed. Philadelphia: Lippincott Williams\&Wilkins; 2005. p. 257-403.

24. Proctor MR, Bauer SB, and Scott RM: The effect of surgery for split spinal cord malformation on neurologic and urologic function. Pediatr Neurosurg 2000; 32:13-19.

25. Lersten M, Duhon B, Laker SR. Diastematomyelia as an incidental finding lumbar on magnetic resonance imaging. PMR 2017;9:95-7.

26. Berger S, Hasler CC, Grant CA, Zheng G, Schumann S, Büchler $P$. A software program to measure the three dimension allength of the spine from radiographic images: validation and reliability assessment for adolescent idiopathic scoliosis. Comput Methods Programs Biomed. 2017;138:57-64.

27. Wang T, Gu JW, Shi TJ, Li K, Wang W, Bai XJ, Zhang JH, Yang ZF, Cui SJ. Surgical management of 142 cases of split cord malformations associated with osseous divide. Neurol Neurochir Pol. 2017;51(6):459-464.

28. Anderson NG, Jordan S, MacFarlane MR. Diastometamyelia: diagnosis by prenatal sonography. Am J Roentgenol 1994; 163: 911-914.

29. Bulsara KR, Zomorodi $A R$, Enterline DS. Thevalue of magnetic resonance imaging in the evaluation of fatty filum terminale. Neurosurg 2004; 54: 375-379.

30. İzci Y, Gönül M, Gönül E. The diagnostic value of skin lesions in split cord malformations. J ClinNeurosci 2007; 14: 860-863.

31. Turhan T, Erşahin Y. Ayrık omurilik malformasyonları. Türkiye Klinikleri J Neurosurg-Special Topics 2011; 4: 31-37.

32. İskandar BJ, Fulmer BB, Hadley MN, Oakes WJ. Conjenital tethered spinal cord syndrome in adults. Neurosurg Focus 2001; 10:7.

33. Klekamp J. Tetheredcord syndrome in adults. J NeurosurgSpine.2011;15:258-70.

34. Boop FA, Chadduck WM. Repair of diastometamyelia. In: Rengachary SS, Wilkins RH (eds). Neurosurgical Operative Atlas. Vol: 3. AANS Publication Committee. Baltimore: Williams\&Wilkins, 1993: 221-225 